\title{
In vitro, evaluation of some medicinal plants extracts against Fusarium oxysporum $f$. sp. lycopersici
}

\author{
Zakaria A. M. Baka*, Mahmoud M. Nour El-Din, Mohammed I. Abodobara, Fatma Elzahra Y. El-Menyer \\ Botany and Microbiology Department, Faculty of Science, Damietta University, Damietta, Egypt.
}

Received: 20 December 2015/ Accepted: 23 February 2016

*Corresponding author: zakariabaka@yahoo.com

\begin{abstract}
This work evaluates the efficacy of aqueous and ethanolic extracts of fourteen medicinal plants as antifungal agents against Fusarium oxysporum f. sp. lycopersici. Extracts were used at five concentrations $(0.0,0.5,1.5,2.5,5 \% \mathrm{w} / \mathrm{v})$. Allium sativum was the most efficient when used in both aqueous and ethanolic extracts, followed by Datura stramonium whereas the least effective species were Lantana camara and Ficus elastica. In general, the ethanolic extract exhibited a more potent inhibitory effect on the growth of $F$. oxysporum f. sp. lycopersici than the aqueous extract, and this was particulary evident for Citrus reticulata, Eucalyptus rostrata, Mentha piperita, Cupressus macrocarpa and Eugenia jambolana. However, Allium sativum and Datura stramonium were the most potent species in addition to Malva parviflora, Althaea rosea, Nigella sativa and Artemisia herba-alba. The dose-response relationship differed according to plant species and the extract used.

Keywords: Fusarium oxysporum f. sp. lycopersici, Antifungal activity, Fusarium wilt, Plant extracts.
\end{abstract}

\section{Introduction}

Tomato (Solanum lycopersicon L.) is an important vegetable crop in Egypt. It is grown in winter, summer and autumn, representing 3\% of Egypt's available planting land (Glala $\boldsymbol{e t}$ al., 2005). It has diversified use high nutritive value, particularly as a source of vitamins A and C; In addition, it has the protective effect by virtue of its content of valuable bioactive components with antioxidant properties (Borguini and Ferraz Da Silva Torres, 2009). Fusarium oxysporum f. sp. lycopersici W.C Snyder and H.N. Hans is the causal agent of vascular wilt disease of tomato. This pathogen is a soil- borne facultative parasite. The pathogen enters the host roots directly through penetration hyphae and colonizes the cortex by intracellular and intercellular growths (Fuchs et al., 1997; Pietro et al., 2001). As in other fusaria, its identification has generally been based on morphological criteria such as the shape of micro and macroconidia, the structure of microconidiophores, formation and disposition of chlamydospores (Henni et al., 1994; Pietro et al., 2003).

As Fusarium wilt disease of tomato is a soil-borne in nature, application of fungicides to control this disease is not practical and expensive. These chemicals have a serious effect on human health, contaminate the environment and kill various beneficial microorganisms (Hayes and Laws, 1991). Also, frequent application of fungicides leads to the developing of new resistant 
strains of pathogens (Smith and Littrell, 1980). Williams (1984) reported that the resistance expressed by a set of cultivars in one geographical region may not be effective in another region due to the existence of pathogens and/ or the variability in environmental conditions.

The previous factors emphasize the need for new methods of plant disease control (Wilson et al., 1987). So, there is an urgent need to find safer alternatives to fungicides for both human and the environment. The natural substances present in plants, fruits, vegetables, oil seeds, and herbs are considered as antioxidants and functional foods (Kitts et al., 2000). Environment-friendly plant extracts have been shown to be of great potential as alternative to the synthetic fungicides (Zhang et al., 2005). The plant extracts are considered as cheap, non-toxic, available and easily biodegradable.The antimicrobial properties of plant extracts have been reported with increasing frequency from different parts of the world (Cowan, 1999). Natural plant substances include large source of effective secondary metabolites such as phenolics, alkaloids, tannins, saponins, glycosides and flavonoids, which may exert an antifungal activity (Hassan and Maswada, 2012; Maswada and Elzaawely, 2013).

However, the aim of this study is to evaluate in vitro, some medicinal plant extracts for controlling Fusarium oxysporum f. sp. lycopersici, the causal agent of wilt disease of tomato.

\section{Materials and Methods}

\section{Fungal strain used:}

Fusarium oxysporum f. sp. lycopersici was kindly provided by the Department of Plant pathology, Faculty of Agriculture, Mansoura University. Fusarium was grown on potato dextrose agar (PDA) medium and incubated at the laboratory conditions $\left(25^{\circ} \mathrm{C}\right)$ for 7 days.

\section{Preparation of potato dextrose agar (PDA) medium}

Two hundred g of potato extract and $20 \mathrm{~g}$ of glucose that added to one liter of distilled water. After the dissolving of all glucose by stirring, then the total volume was distributed to desired volumes in conical flasks. After that the agar was added in a percent of $2 \%$ and autoclaved at 15 p.s.i. and $121^{\circ} \mathrm{C}$ for $15 \mathrm{~min}$.

\section{Plant samples collection:}

Fourteen plant species were collected from the natural habitats (Table 1). The plant species were identified according to Boulos (2005), and deposited as herbarium sheets at Botany Department, Faculty of Science, Damietta University.

Table 1. List of plant species used for preparing extracts

\begin{tabular}{llll}
\hline Scientific name & Family name & Part used & Common name \\
\hline Allium sativum L. & Liliaceae & Bulb & Garlic \\
Althaea rosea L. & Malvaceae & Leaves & Hollyhock \\
Artemisia herba-alba Asso. & Asteraceae & Shoots & White wormwood \\
Citrus reticulata Blanco. & Rutaceae & Peels & Mandarin peels \\
Cupressus sempervirens L. & Cupressaceae & Leaves & Mediterranean cypress \\
Datura stramonium L. & Solanaceae & Leaves & Datura \\
Eucalyptus rostrata L. & Myrtaceae & Leaves & Camphor \\
Eugenia jambolana Lam. & Myrtaceae & Leaves & Jambolin \\
Ficus elastica Var. & Moraceae & Leaves & rubber plant \\
Juniperus oxycedrus L. & Cupressaceae & Seeds & Prickly juniper \\
Lantana camara L. & Verbenaceae & Leaves & Tickberry wild sage \\
Malva parviflora L & Malvaceae & Leaves & Egyptian mallow \\
Mentha piperita L. & Lamiaceae & Leaves & Peppermint \\
Nigella sativa L. & Ranunculaceae & Seeds & Black seeds \\
\hline
\end{tabular}

\section{Drying of plant samples}

The plant materials were air-dried until being crispy. Dried plants parts were ground into a fine powder using a blender and sieved to remove coarse particles. 


\section{Preparation of plant extracts}

A known weight $(5 \mathrm{gm})$ of powdered plant material was extracted with $50 \mathrm{ml}$ of $95 \%$ ethanol, boiling distilled water. The conical flask was covered with aluminum foil to prevent the contamination and extracted on a shaker at 150 $\mathrm{rpm}$ for 24 hours at $25^{\circ} \mathrm{C}$. The mixture was filtered through sterile Whatman filter paper No.1. In case of the ethanolic extract, ethanol was completely evaporated at $45^{\circ} \mathrm{C}$ and the residue was resuspended in $10 \mathrm{ml}$ of distilled water. Different volumes $(0,1,3,5$ and $10 \mathrm{ml})$ were taken into 20 PDA medium for $0.0,0.5,1.5,2.5$ and $5 \%(\mathrm{w} / \mathrm{v})$ extract, respectively.

\section{Antifungal assay}

The antifungal assay was done according to the procedure of Kumar et al. (2009) with some modifications. About 1, 3, 5, $10 \mathrm{ml}$ of aqueous and ethanolic plant extracts were taken into $20 \mathrm{ml}$ liquid PDA medium to give the concentrations of $0.0,0.5,1.5,2.5$ and $5 \% \mathrm{w} / \mathrm{v}$ and tested against Fusarium oxysporum f. sp. lycopersici, then 7-mm inoculum-disc of the fungus was placed in the center on solid PDA medium and incubated at $25^{\circ} \mathrm{C}$ for 7 days. The diameter of fungal growth $(\mathrm{cm})$ was measured and the inhibition of fungal growth was estimated as a percentage of the control. The relative potency of plant extract was estimated in terms of the concentration leading to $50 \%$ inhibition of fungal growth $\left(\mathrm{LC}_{50}\right)$.

\section{Statistical analysis:}

The relative inhibition of fungal growth estimated as a percentage of the control was arcsine transformed before performing statistical analysis to ensure homogeneity of variance. Data were analyzed using SPSS (SPSS, 2004) version 22 and mean separation was performed using the Duncan's multiple range test at $\mathrm{p}<0.05$ (Duncan, 1955).

\section{Results}

Treatments (plant species, extractant and concentration of the extract) had a highly significant effect $(\mathrm{P}<0.001)$ on growth of $F$. oxysporum f. sp. lycopersici was shown in Table 2. Aqueous and ethanolic extracts of 14 plant species were tested against $F$. oxysporum f. sp. lycopersici in five concentrations $(0,0.5,1.5,2.5$ and 5\%). Table 3 shows that the most active plant species was Allium sativum with an average inhibition for aqueous and or ethanolic extracts of $61 \%$ and 54\%, respectively, followed by Datura stramonium and Citrus reticulata with an average inhibition of $40 \%$ for both aqueous and ethanolic extracts; whereas the least effective species were Lantana camara and Ficus elastica with an average inhibition of $0.5 \%$ and $12 \%$ for aqueous and ethanolic extracts, respectively. Figure 1 shows that the most effective aqueous and ethanolic plant extracts on the growth of Fusarium oxysporum f. sp. lycopersici at the concentration of $5 \%$ in both of Allium sativum and Datura stramonium. The remaining plant species exhibited a moderate inhibition, depending on the type of used extract.

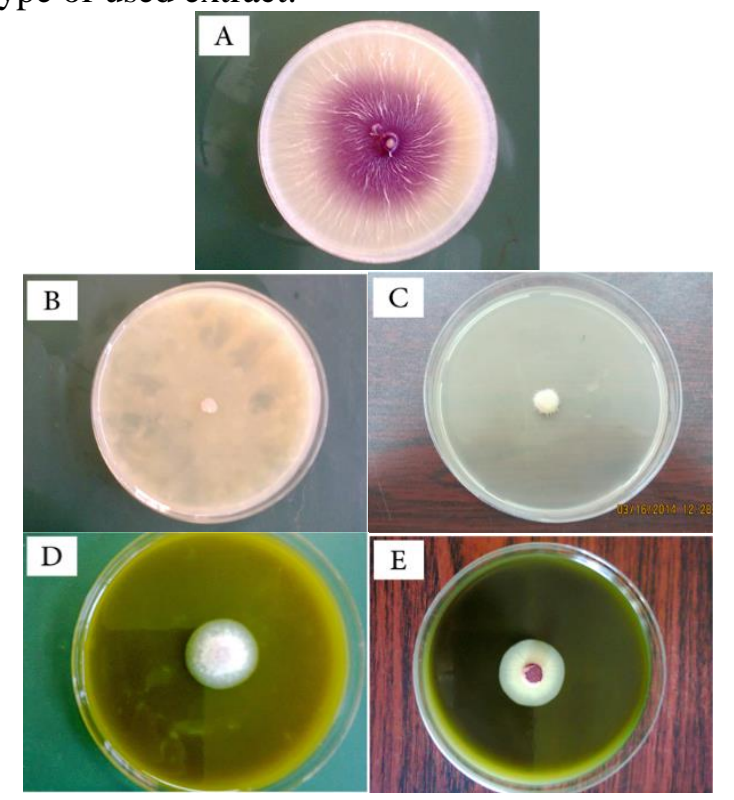

Fig.1. Effect of the most effective plant extracts on the growth of Fusarium oxysporum $\mathrm{f}$. sp. lycopersici at the concentration of 5\%. A. control; B. aqueous Garlic extract; C. ethanolic Garlic extract; D. aqueous Datura extract; E. ethanolic Datura extract.

In general, the ethanolic extract exhibited a potent inhibitory effect on the growth of $F$. oxysporum $\mathrm{f}$. sp. lycopersici than the aqueous extract, and this was particularly evident for Citrus reticulata, Eucalyptus rostrata, Mentha piperita, Cupressus sempervirens and Eugenia jambolana. However, Allium sativum and Datura stramonium were the most potent species in addition to Malva parviflora, Althaea rosea, Nigella sativa and Artemisia herba-alba. Increasing concentration of the plant extract led to a progressive inhibition of fungal growth; yet the dose-response relationship differed according to plant species and the type of extract. For example, a saturable trend was found in both ethanolic and aqueous extracts of Allium 
sativum, Datura stramonium, Citrus reticulata and ethanolic extract of Ficus elastica, Eucalyptus rostrata and Cupressus sempervirens, and aqueous extract of Eugenia jambolana and Althaea rosea were recorded. In addition, a linear trend was found in both extracts of Juniperus oxycedrus, Nigella sativa, Mentha piperita, Artemisia herba-alba, Lantana camara and Malva parviflora as well as the ethanolic extracts only of Eugenia jambolana and Althaea rosea and aqueous extracts only of Eucalyptus rostrata, Ficus elastica and Cupressus sempervirens were detected in Figures 2, 3 and 4.
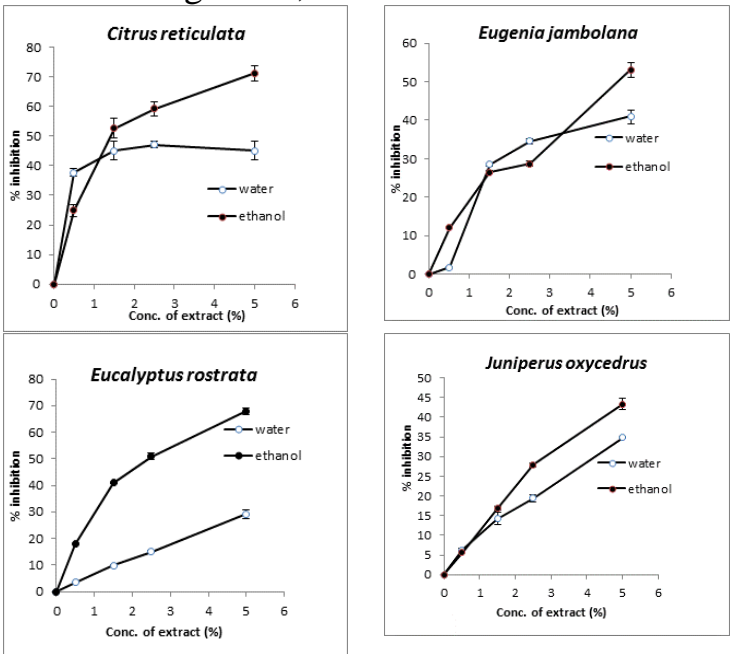

Fig.2. Effect of aqueous and ethanolic extracts of Citrus reticulata, Eugenia jambolana, Eucalyptus rostrata and Juniperus oxycedrus on growth of $F$. oxysporum f. sp. lycopersici. Each value is the mean of three replicates \pm S.E.
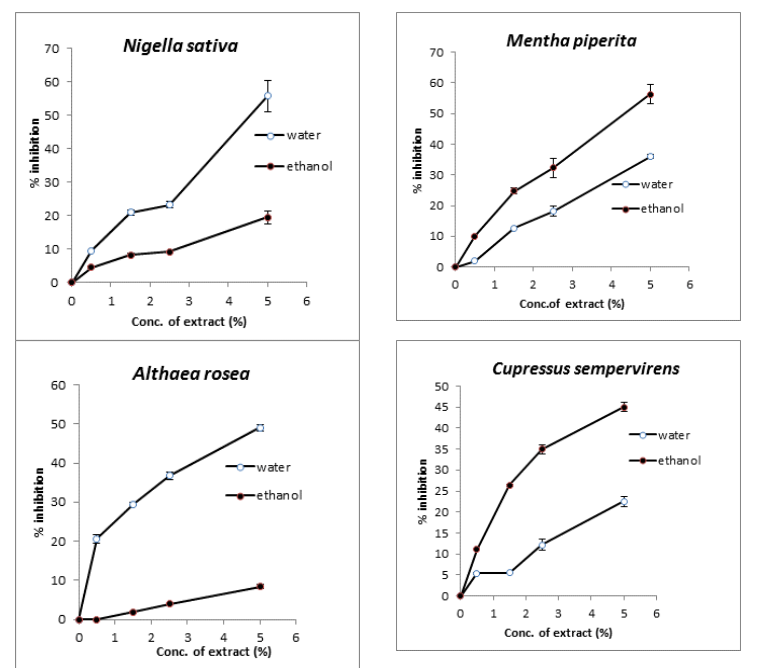

Fig.3. Effect of aqueous and ethanolic extracts of Nigella sativa, Mentha piperita, Althaea rosea and Cupressus sempervirens on growth of $F$. oxysporum $\mathrm{f}$. sp. lycopersici. Each value is the mean of three replicates \pm S.E.
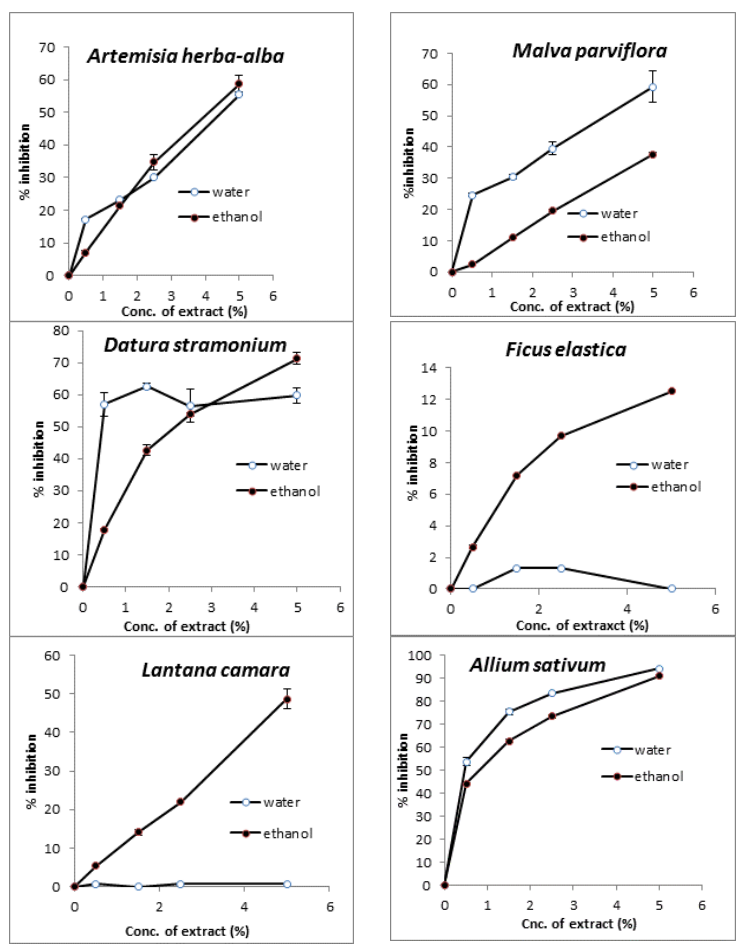

Fig.4. Effect of aqueous and ethanolic extracts of Artemisia herba-alba, Malva parviflora, Datura stramonium, Ficus elastica, Lantana camara and Allium sativum on growth of $F$. oxysporum f. sp. lycopersici. Each value is the mean of three replicates \pm S.E.

Table 4 showed the relative potency of the aqueous and ethanolic extracts of the examined plant species against $F$. oxysporum f. sp. lycopersici in terms of $\mathrm{LC}_{50}$, calculated from the dose-response relationships of Figures 2, 3 and 4. The effective concentration of the aqueous extract at which $50 \%$ pathogen inhibition occurred was $0.45 \%$ for both Allium sativum, Datura stramonium, $3.8 \%$ for Malva parviflora, $4.45 \%$ for Artemisia herba-alba and $4.55 \%$ for Nigella sativa. The value of $\mathrm{LC}_{50}$ of the ethanolic extract was $0.8 \%$ for Allium sativum, $1.4 \%$ for Citrus reticulata, $2.1 \%$ for Datura stramonium and $2.4 \%$ for Eucalyptus rostrata.

Table 2. ANOVA of the effect of the main factors (plant species, type of extract and concentration of the extract) and their interactions on the inhibition percentage of $F$. oxysporum f. sp. lycopersici

\begin{tabular}{llll}
\hline Source of variation & df & F & Sig. \\
\hline Species & 13 & 1181.542 & .000 \\
Extractant & 1 & 19.400 & .000 \\
Conc. & 4 & 4842.088 & .000 \\
Species * Extractant & 13 & 284.078 & .000 \\
Species * Conc. & 52 & 97.975 & .000 \\
Extractant * Conc. & 4 & 87.894 & .000 \\
Species * Extractant * Conc. & 52 & 40.459 & .000 \\
\hline
\end{tabular}


Table 3. Effect of plant extracts on the growth of $F$. oxysporum f. sp. lycopersici. Each value is the mean of 3 replicates $\pm \mathrm{SE}$. Means with common letters are highly significant different at $\mathrm{p}<0.05$

\begin{tabular}{lcc}
\hline \multicolumn{1}{c}{ Plant species } & $\begin{array}{c}\text { Inhibition of } \\
\text { fungal } \\
\text { growth } \\
\text { Aqueous } \\
\text { extract }\end{array}$ & $\begin{array}{c}\text { (\% of } \\
\text { control) } \\
\text { Ethanolic } \\
\text { extract }\end{array}$ \\
\hline Lantana camara & $0.45 \pm 0.09^{\mathrm{a}}$ & $18.0 \pm 4.56^{\mathrm{e}}$ \\
Ficus elastica & $0.52 \pm 0.17^{\mathrm{ab}}$ & $6.41 \pm 1.21^{\mathrm{b}}$ \\
Cupressus & $9.10 \pm 2.09^{\mathrm{c}}$ & $23.5 \pm 4.33^{\mathrm{g}}$ \\
sempervirens & $11.5 \pm 2.76^{\mathrm{d}}$ & $35.5 \pm 6.42^{\mathrm{k}}$ \\
Eucalyptus rostrata & $13.7 \pm 3.48^{\mathrm{e}}$ & $24.7 \pm 5.23^{\mathrm{ghij}}$ \\
Mentha piperita & $15.0 \pm 3.21^{\mathrm{f}}$ & $18.7 \pm 4.17^{\mathrm{ef}}$ \\
Juniperus oxycedrus & $21.1 \pm 4.56^{\mathrm{g}}$ & $24.0 \pm 4.78^{\mathrm{gh}}$ \\
Eugenia jambolana & $21.9 \pm 5.10^{\mathrm{gh}}$ & $8.26 \pm 1.75^{\mathrm{c}}$ \\
Nigella sativa & $25.1 \pm 4.83^{\mathrm{i}}$ & $24.4 \pm 5.62^{\mathrm{ghi}}$ \\
Artemisia herba-alba & $27.1 \pm 4.40^{\mathrm{j}}$ & $2.83 \pm 0.83^{\mathrm{a}}$ \\
Althaea rosea & $30.7 \pm 5.26^{\mathrm{k}}$ & $14.1 \pm 3.64^{\mathrm{d}}$ \\
Malva parviflora & $35.0 \pm 4.81^{\mathrm{l}}$ & $41.6 \pm 6.94^{\mathrm{m}}$ \\
Citrus reticulata & $47.1 \pm 6.43^{\mathrm{m}}$ & $37.1 \pm 6.80^{\mathrm{kl}}$ \\
Datura stramonium & $61.3 \pm 8.92^{\mathrm{n}}$ & $54.1 \pm 8.29^{\mathrm{n}}$ \\
Allium sativum & & \\
\hline Total of all species & $22.83 \pm 1.64^{\mathrm{a}}$ & $23.8 \pm 1.62^{\mathrm{b}}$ \\
\hline
\end{tabular}

Table 4. The concentration of plant extracts leading to $50 \%$ inhibition of $F$. oxysporum f. sp. lycopersici growth $\left(\mathrm{LC}_{50}\right)$

\begin{tabular}{lcc}
\hline \multirow{2}{*}{ Plant species } & \multicolumn{2}{c}{ LC50 $\left.^{\circ} \% \mathrm{w} / \mathrm{v}\right)$} \\
\cline { 2 - 3 } & $\begin{array}{c}\text { Aqueous } \\
\text { extract }\end{array}$ & $\begin{array}{c}\text { Ethanolic } \\
\text { extract }\end{array}$ \\
\hline Lantana camara & - & - \\
Ficus elastica & - & - \\
Cupressus sempervirens & - & - \\
Eucalyptus rostrata & - & 2.4 \\
Mentha piperita & - & 4.3 \\
Juniperus oxycedrus & - & - \\
Eugenia jambolana & - & 4.65 \\
Nigella sativa & 4.55 & - \\
Artemisia herba-alba & 4.45 & 4.05 \\
Althaea rosea & - & - \\
Malva parviflora & 3.80 & - \\
Citrus reticulata & - & 1.4 \\
Datura stramonium & 0.45 & 2.1 \\
Allium sativum & 0.45 & 0.8 \\
\hline
\end{tabular}

\section{Discussion}

The extracts of fourteen plant species investigated in the present study exhibited diverse antifungal activities against $F$. oxysporum $\mathrm{f}$. sp. lycopersici which varied according to the plant species and type of extract. In general, aqueous and ethanolic extracts of Allium sativum and Datura stramonium exhibited the potent effect on the pathogen. The aqueous extract of Lantana camara was the least effective on the pathogen. Moreover, the ethanolic extract of Althaea rosea was the least effective on the pathogen. The antifungal activity of plant extracts may be related to the presence of many bioactive compounds such as flavonoids, terpenoids, alkaloids, tannins, steroids, glycosides and phenolics (Leicach $\boldsymbol{e t}$ al., 2010; Yaber Grass and Leicach, 2011). These secondary metabolites, also known as allelochemicals, are normally produced by the medicinal plants to provide protection against stress conditions, invasion of pathogens and also involved in the plant-plant interaction; thus allowing the successful survival of the plant against other species and the invading microorganisms (Matsuki et al., 2011).

Aqueous extract of garlic showed a better activity than that of ethanol. Previous studies supported these results (Gull et al., 2012). Garlic was reported to have antifungal properties and inhibit formation of aflatoxins (Graham and Graham, 1987) and penicillic acid (Ismaiel, 2009). The antimicrobial activity of garlic is totally dependent on the allicin compound. Studying the antimicrobial properties of garlic indicated that garlic is full of anion compounds, including nitrates, chlorides, sulfides and organosulphur compounds that can be easily resolved in water and are responsible for antibacterial properties (Shobana et al., 2009). Srivastava and Yadav (2008) evaluated extracts of 45 medicinal plants against $F$. oxysporum $\mathrm{f}$. sp. lycopersici and proved the antifungal properties of these medicinal plants. These results were also obtained by Ranawane et al. (2010) who reported that Datura stramonium extract had the inhibitory effect against the growth of many fungal species. Also, Sharma et al. (2014) investigated that the aqueous leaf extracts of Datura stramonium had the antimicrobial activity against Alternaria solani and Fusarium oxysporum. Datura stramonium plants contain bioactive compounds such as hyoscyamine, scopolamine and atropine in the seeds and flowers, besides its hallucinogen activity (Rajesh and Sharma, 2002; Kaushik and Goyal, 2008).

The ethanolic extract of Citrus reticulata is better than its aqueous extract; this can be related to its content of flavonoids, tannins, phenolics, vitamin $\mathrm{C}$, proteins and carbohydrates. High flavonoid content expressed as catechin equivalent was found in the ethanolic extract (92.4mg CT/gm). Vitamin C content was 115.5 $\mathrm{mg} \mathrm{AAE} / \mathrm{gm}$, tannin content was $132 \mathrm{mg}$ TAE/gm (Justin et al., 2014). The aqueous extract of Malva parviflora showed better activity than the ethanolic extract. These results are in agreement with those of Abdel-Ghani et al. (2013). The antifungal activity of Malva might be due to the presence of alkaloids, essential oils and phenolic 
quleoside as reported by Abad $\boldsymbol{e t}$ al. (2007). The antifungal activity of Artemisia herba-alba might be due either to the flavonoids or to the combine effect of glycosides, saponins, alkaloids, tannins and flavonoids (Juvatkar et al., 2012). The aqueous extract of Nigella sativa showed more antifungal activity than the ethanolic extract which coincides with the results of Zahra $\boldsymbol{e t}$ al. (2011) and this may be due to the higher content of glycosides, tannins, saponins, flavonoids and alkaloids in the aqueous extract. Antifungal activity of thymoquinone, present in Nigella sativa, against Aspergillus niger was reported (Al Jabre et al., 2003). The antifungal potency of plant extracts was estimated in terms of the relative inhibition of fungal growth below the control. Nevertheless, this efficiency can be estimated also in terms of the $\mathrm{LC}_{50}$. The results of $\mathrm{LC}_{50}$ revealed that Allium sativum was the most efficient in both aqueous and ethanolic extracts and Datura stramonium came next with the lowest $\mathrm{LC}_{50}(0.45 \%$ as an average of the aqueous extract of the 2 species and $0.8 \%$ and $2.1 \%$ for ethanolic extract of Allium sativum and Datura stramonium, respectively). Normally, the lower the $\mathrm{LC}_{50}$ the more potent is the antifungal activity of the extract; and whenever an extract has no value for $\mathrm{LC}_{50}$, this means that the antifungal activity of this extract is too weak to the extent that the relative inhibition of fungal growth never attained 50\% even at the top concentration used $(5 \% \mathrm{w} / \mathrm{v})$. These results are in agreement with previous reports (Alkhail, 2005; Shrestha and Tiwari, 2009; Taskeen-Un-Nisa and Mir, 2010).

\section{Acknowledgement}

The authors would like to thank Dr. Taha ElKatony, Botany Department, Faculty of Science, Damietta University for his kind help concerning the statistical analysis of the data.

\section{References}

Abad M.J., Ansuategui M. andBermejo P. (2007). Active antifungal substances from natural sources. Arkivoc, 7, 116-145.

Abdel-Ghani A. E., Hassan, H. M. and El-Shazly, A. M. (2013). Phytochemical and biological study of Malva parviflora L. grown in Egypt. Methods, 22, 17-25.

Al Jabre S., Al Akloby O. M., Al Qurashi A. R., Al Dossary A., Akhtar N. and Randhawa M.A. (2003). Thymoquinone, an active principle of Nigella sativa, inhibited Aspergillus niger. Pak. Med. Net., 42, $102-104$.

Alkhail A.A. (2005). Antifungal activity of some extracts against some plant pathogenic fungi. Pak. J. Biol. Sci., 8, 413-417.

Borguini R. G. and Ferraz Da Silva Torres E. A. F. (2009). Tomatoes and tomato products as dietary sources of antioxidants. Food Rev. Intern., 25, 313325.

Boulos L. (2005). Flora of Egypt. AlHadara Publishing, Cairo, Egypt (Vol.1-4).

Cowan M.M. (1999). Plant products as antimicrobial agents. Clin. Microbiol. Rev., 12, 564-582.

Duncan D.B. (1955). Multiple range and multiple F tests. Journal of the International Biometrics Society, 11, 1-42.

Fuchs J.G., Moenne-Loccoz Y. and Defago G. (1997). Nonpathogenic Fusarium oxysporum strain Fo47 induces resistance to Fusarium wilt in tomato. Plant Dis., 81, 492-496.

Glala A.A., Hoda A.M. and Fawzi Z.F. (2005). Improving tomato plant growth, health, earliness, productivity and fruit quality by chemically induced systematic resistance. J. Appl. Sci. Res. 1, 362-372.

Graham H.D. and Graham E.J.F. (1987). Inhibition of Aspergillus parasiticus growth and toxin production by garlic. J. Food Safety, 8,101- 108.

Gull I., Saeed M., Sahukat H., Aslam S.M., Samra Z.Q. and Athar A.M. (2012). Inhibitory effectof Allium sativum and Zingiber officinale extracts on clinically important drug resistant pathogenic bacteria. Ann. Clin. Microbiol. Antimicrob., 11,16.

Hassan N.S. and Maswada H.F. (2012). Proximate and phytochemical analyses of Asparagus stipularis and Cyperus capitatus and their antioxidant activities. Proceedings of the 11th Conference of the Agricultural Development Researches, 27-30, Ain Shams University, Egypt.

Hayes W.J. and Laws E.R. (1991). Handbook of Pesticide Toxicology, Vol.1.Academic Press, India.

Henni J.E., Boisson C. and Geiger J.P. (1994).Variability in the morphology of Fusarium oxysporum f.sp.lycopersici. Phytopathol. Medit., 33, 51-58.

Ismaiel A.A. (2009). Inhibitory effect of Egyptian garlic extract on penicillic acid production. Egypt. J. Microbiol., 44, 1 - 14.

Justin J.S., Milton A. and Natesan G. (2014). Phytochemical evaluation of peel of Citrus reticulata Blanco using various solvent extracts. Intern. J. Pharm. Sci. Bus. Manag., 2, 26-35.

Juvatkar P.V., Kale M.K., Jalalpure S.S., Sandeep W., Pravin N. and Vishal J. (2012). Antimicrobial activity of leaves of Artemisia vulgaris L., Ph. D. Thesis, Department of Pharmacognosy and 
Phytochemistry Konkan Gyanpeeth Rahul Dharkar College of Pharmacy, Karjat, Dist-Raigadh.

Kaushik P. and Goyal P. (2008). In-vitro, evaluation of Datura innoxia (thorn-apple) for potential antibacterial activity. Ind. J. of Microbiol., 48, 353357.

Kitts D.D., Wijewickreme A.N. and Hu C. (2000). Antioxidant properties of a North American ginseng extract. Molec. Cell Biochem., 203,1-10.

Kumar N., Singh R.K., Adaj M.N. and Singh R.B. (2009). Effect of aqueous leaf and bark extracts of Mimusops elengi (L.) on radial growth and sclerotial formation of Sclerotinia sclerotiorum (Lib.) De Bary, a polyphagous fungus. Protect. Agric. Technol., 5, 288-300.

Leicach S.R., Garau A.M., Guarnaschelli A.B., Yaber Grass M.A., Sztarker N.D. and Dato, A. (2010). Changes in Eucalyptus camaldulensis essential oil composition as response to drought preconditioning. J. Plant Interac., 5, 205-210.

Maswada H.F. and Elzaawely A.A.(2013). Nutritive value of Stipagrostis lanata (Forssk.) De Winter as a feed for livestock. Asian J. Crop. Sci., 5, 216-221.

Matsuki M., Foley W.J. and Floyd R.B. (2011). Role of volatile and non-volatile plant secondary metabolites in host tree selection by Christmas beetles. J. Chem. Ecology, 37, 286-300.

Pietro A.D., Huertas-González M.D., Gutierrez-Corona J.F., Martínez-Cadena G., Méglecz E. and Roncero M.I.G. (2001). Molecular characterization of a subtilase from the vascular wilt fungus Fusarium oxysporum. Molec. Plant-Microbe Interact., 14, 653-662.

Pietro A.D., Madrid M.P., Caracuel Z., Delgado-Jarana J. and Roncero M.I.G. (2003). Pathogen profile Fusarium oxysporum: Exploring the molecular arsenal of a vascular wilt fungus. Mol. Plant Pathol., 4, 315-325.

Rajesh A. and Sharma G.L. (2002). Studies on antimycotic properties of Datura metel. J. Ethnopharmacol., 80, 193-197.

Ranawane A., Singh V. and Nimbkar N. (2010). Invitro antifungal study of the efficacy of some plant extracts for inhibition of Alternaria carthami fungus. Indian Journal of Natural Products and Resources, 1, 384-386.
Sharma B., Srivastava K. K., Verma N., Niwas R. and Singh M. (2014). Antifungal potential of leaf extract of Datura stramonium L., against some important plant pathogenic fungi. Acta Biologica Indica, 3, 659-662.

Shobana S., Vidhya V.G. and Ramya M. (2009). Antibacterial activity of garlic varieties (ophioscordon and sativum) on enteric pathogens. Curr. Res. J. of Biol. Sci.,1,123-6.

Shrestha A.K. and Tiwari R.D. (2009). Antifungal activity of crude extracts of some medicinal plants against Fusarium solani (Mart.) Sacc. Ecoprint: An Intern. J. Ecology, 16, 75-78.

Smith D.H. and Littrell R.H. (1980). Management of peanut foliar diseases with fungicides. Plant Dis., 64,356-361.

SPSS (2004). SPSS base 13.0 for windows user's guide. SPSS Inc., Chicago.

Srivastava D. K. and Yadav H. L. (2008). Antifungal activity of some medicinal plants against Fusarium oxysporum f. sp. lycopersici. Indian Phytopathology, 61, 99-102.

Taskeen-Un-Nisa A.H. and Mir R.A. (2010). Antimycotic activity ofplant extracts on the spore germination of some pathogenic fungi. Mycopathol., 8: 65-69.

Williams R.J. (1984). Downy mildew of tropical cereals.Advances in Plant Pathology, 2, 1-103.

Wilson C.L., Faklin J.D. and Otto B.E. (1987). Fruit volatiles inhibitory to Monilinia freuticola and Botrytis cinerea. Plant Disease, 71,316-319.

Yaber Grass M.A. and Leicach S.R. (2011). Changes in Senecio grisebachii pyrrolizidine alkaloids abundances and profiles as response to soil quality. Journal of Plant Interactions, 7, 175-182.

Zahra N., Jahan N., Nosheen S. and Khalil-ur-Rehman. (2011). Antimicrobial activity of aqueous, ethanolic extracts and crude extracted phytoconstituents of Nigella sativa seeds. Bioscience Research, 8, 19-25.

Zhang H.Y., Zheng X.D. andXi Y.F. (2005). Biological control of post-harvest blue mold of oranges by Cryptococcus laurentii (Kufferath) Skinner. Bio Control, 50, 331-334. 
الملخص العربي

عنوان البحث: تقييم مستخلصات بعض التباتات الطبية ضد فطر فيوزاريم اوكسيسبورم ليكوبرسيسي زكريا عوض محمد بقا ومحمود متولى نور الدين ومحمد إسماعيل ابو دبارة و فاطمه الزهراء يوسف المنير

$$
\text { قسم النبات والميكربيولوجى - كلية العلوم - جامعة دمياط }
$$

في هذا البحث تم تقييم فعالية المستخلصات المائيه والايثانولية لأربعة عشر نباتاً طبياً تم جمعهم من البيئة البئة

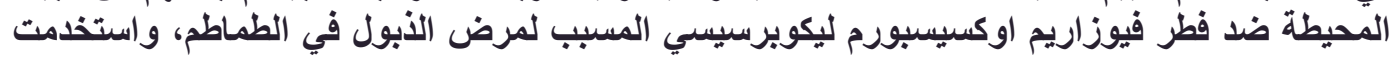

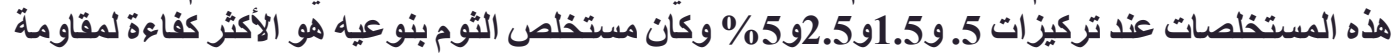

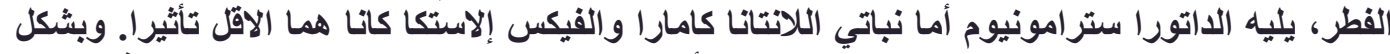

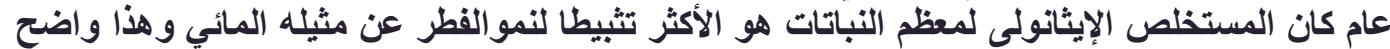

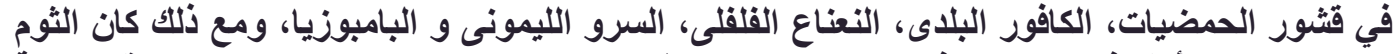

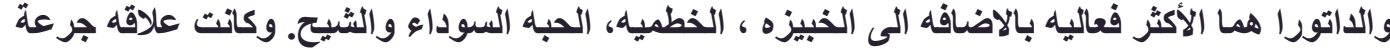
الاستجابة تختلف طبقا لأنواع النباتات و نوع الافه المستخلص. 